\title{
Bcl-2-Binding Component 3
}

National Cancer Institute

\section{Source}

National Cancer Institute. BCl-2-Binding Component 3. NCI Thesaurus. Code C91774.

Bcl-2-binding component 3 (193 aa, $21 \mathrm{kDa}$ ) is encoded by the human BBC3 gene. This protein plays a role in the regulation of apoptosis. 